\title{
Morphometry of Liver Fluke (Fasciola Gigantica) Infecting Balinese Cattle
}

\author{
Putu Anna Oktaviana ${ }^{1}$, Nyoman Adi Suratma ${ }^{2}$, I Nengah Wandia ${ }^{3 *}$ \\ ${ }^{1}$ Student of Veterinary Postgraduate Udayana University \\ 2 Parasitology Labvoratory of Veterinary Faculty Udayana University. \\ ${ }^{3}$ Laboratory of Primate Udayana University \\ Udayana, Bali \\ *Corresponding Author: wandia@unud.ac.id
}

\begin{abstract}
Fasciola hepatica and Fasciola gigantica belong to Trematoda family which can cause fasciolosis. Fasciola hepatica is commonly found in temperate climates, while Fasciola gigantica is found in areas with wet tropical climates. Research on Fasciola gigantica especially in Bali is still very little, was just limited to the prevalence, epidemiology and histopathology of liver. This study aims to determine the morphometry of Fasciola gigantica infecting Bali cattle in Bali. This descriptive study used 43 samples of worms. Measurement of morphometry is done by microscope equipped with camera Axio Cam ERc 5S and software used is IMAGEJ and ZEN LITE. The morphometric analysis showed that there were two differentiating factors that is PB (Body Length) and LB (Body Width). The morphometric of Fasciola gigantica in Bali is smaller compared to Fasciola gigantica in general but larger than Fasciola hepatica.
\end{abstract}

\section{Keywords: morphometry, Fasciola gigantica, bali cattle}

\section{INTRODUCTION}

Fasciola hepatica and Fasciola gigantica are Trematoda families that can cause fasciolosis. Both of these flukes in livestock are transmitted through snails and the Lymnaeidae family. Fasciola hepatica generally found in temperate climates, while Fasciola gigantica is found in areas with wet tropical climates [7].

The incidence of fasciolosis in Egypt has a serious impact on the world of veterinary medicine because it causes death in livestock and affects the health of people of all ages [2]. Two Fasciola species have been identified through morphometric methods by Lofty [8]. In addition, Fasciola hepatica and Fasciola gigantica have also been confirmed in Egypt morphologically [13].

The presence of an intermediate form from Fasciola in Eastern Mediterranean countries has become a problem [4]. In Asia, especially in Japan,
Taiwan, Philippines and South Korea, morphologically, Fasciola species exhibit extraordinary variations [18]. In the Middle East, intermediate forms of Fasciola are reported from Gilan Province in Northern Iran. Sahba reported three Fasciola species namely Fasciola hepatica, Fasciola gigantica, and Fasciola indica using morphometric analysis [16].

Fasciolosis in Indonesia is more common in cattle and buffalo than sheep and goats, generally caused by Fasciola gigantica. Fasciolosis occurs in a wide distribution, especially in wetlands. Indonesia's natural state with rainfall and high humidity, and supported by its hemaproditic properties will accelerate the proliferation of the liver flukes. This fluke attacks many ruminant animals which usually eat grass contaminated with metacercaria, but can also infect humans [9]. 
One study of Fasciola gigantica. is done by Fajar shows that from 290 bali cow stool samples obtained 16 samples $(5.51 \%)$ were positively infected with trematode flukes [3]. After further identification, the type of trematode which infects Bali cattle that are kept in the Bali cattle breeding center in Sobangan village, Mengwi sub-district, Badung district, was infected by Fasciola gigantica by $3.1 \%$. The results of other studies found in Samarinda that the prevalence of Fasciola gigantica was $33.33 \%$ [6]. Another study regarding the prevalence of Fasciola gigantica is in Balinese cattle in the Makassar RPH of 53.95\% [14]. Research on Fasciola gigantica, especially on the island of Bali is still very little, as for the research that has been carried out is limited to the prevalence, epidemiology and histopathology of liver organs. Efforts to against fasciolosis have not been maximized because farmers are rarely prevented from this disease. Therefore, studies on morphometry are important to improve understanding of parasitic epidemiology and disease control. Until now, a lot of research has been done to identify the morphometry of Fasciola gigantica but in Bali particulary there is not enough data.

\section{RESEARCH METHODS}

This research is a descriptive study that uses primary data in the form of Fasciola gigantica in the liver of Bali Cattle in Slaughterhouses. The affordable population in this study is Fasciola gigantica that live in one Bali Cattle. The sampling technique is to do an incision in the liver which is suspected of having Fasciola gigantica infection then take the flukes and put it in storage media. BL and BW measurements are done using IMAGEJ software while OSMax, OSMin, VSMax, VSMin, PHl, PHw and OS-VS use ZEN LITE software with a microscope equipped with Axio Cam ERc 5S camera. Liver flukes that have been stored in physiological $\mathrm{NaCl}$ liquid then placed on an object glass using tweezers and then dripped with lactophenol and closed using a cover glass. Preparations are left for one to two days until the fluke looks transparent and then after that is examined under a microscope equipped with Axio Cam ERc 5S camera.

\section{RESULTS AND ANALYSIS}

\section{Morphometry of Fasciola gigantica}

Morphometry research of Fasciola gigantica was carried out on 43 flukes from 5 cattles. Of the 9 variables examined, the minimum, maximum and average values are presented in Table 1

After the measurement is done, the results show that the general average of all variables in each region is as follows; $\mathrm{PB}$ $27.874 \mathrm{~mm}$, LB $6.378 \mathrm{~mm}$, OSMax 0.122 $\mathrm{mm}$, OSMin $0.112 \mathrm{~mm}$, VSMax 0.204 mm, VSMin $0.195 \mathrm{~mm}$, PP $0.109 \mathrm{~mm}$, LP $0.070 \mathrm{~mm}$ and OS-VS $0.158 \mathrm{~mm}$. The longest size of Fasciola gigantica adaah is $36,484 \mathrm{~mm}$ while the shortest one is $16,064 \mathrm{~mm}$.

\section{Morphometric Differentiating Factor in Fasciola gigantica}

Based on the Principal Component Analysis - Covariance test, there are two components that become a benchmark, Component 1 representing the size and Component 2 representing the shape (Figure 1). LB and PB variables are two variables that located at the farthest point from zero in Component 1 and Component 2. This shows that the two variables are the biggest factors that influence the difference in Fasciola gigantica morphometry in Bali. 
TABEL 1. MORPHOMETRY OF FASCIOLA GIGANTICA WHICH INFECTS BALI CATTLE

\begin{tabular}{lcccc}
\hline Variabel & $\begin{array}{c}\text { Mean } \\
(\mathrm{mm})\end{array}$ & $\begin{array}{c}\text { Minimal } \\
(\mathrm{mm})\end{array}$ & $\begin{array}{c}\text { Maksimal } \\
(\mathrm{mm})\end{array}$ & $\begin{array}{c}\text { Standard } \\
\text { Deviation }\end{array}$ \\
\hline PB & 27,874 & 16,064 & 36,484 & 4,380 \\
LB & 6,378 & 3,421 & 8,257 & 0,935 \\
OSMax & 0,122 & 0,100 & 0,137 & 0,007 \\
OSMin & 0,112 & 0,094 & 0,144 & 0,009 \\
VSMax & 0,204 & 0,178 & 0,240 & 0,013 \\
VSMin & 0,195 & 0,171 & 0,221 & 0,010 \\
PP & 0,109 & 0,075 & 0,132 & 0,012 \\
LP & 0,070 & 0,054 & 0,093 & 0,009 \\
OS-VS & 0,158 & 0,030 & 0,209 & 0,036 \\
\hline
\end{tabular}

Note $\quad:$ PB = Body Length, LB = Body Width, OSMax = Maximum diameter of Oral Sucker, OSMin = Minimum diameter of Oral Sucker, VSMax = Maximum diameter of Ventral Sucker, VSMin = Minimum diameter of Ventral Sucker, PP $=$ Pharynx length, LP $=$ Pharynx width, OS-VS $=$ Jarak antara Oral Sucker dan Ventral Sucker

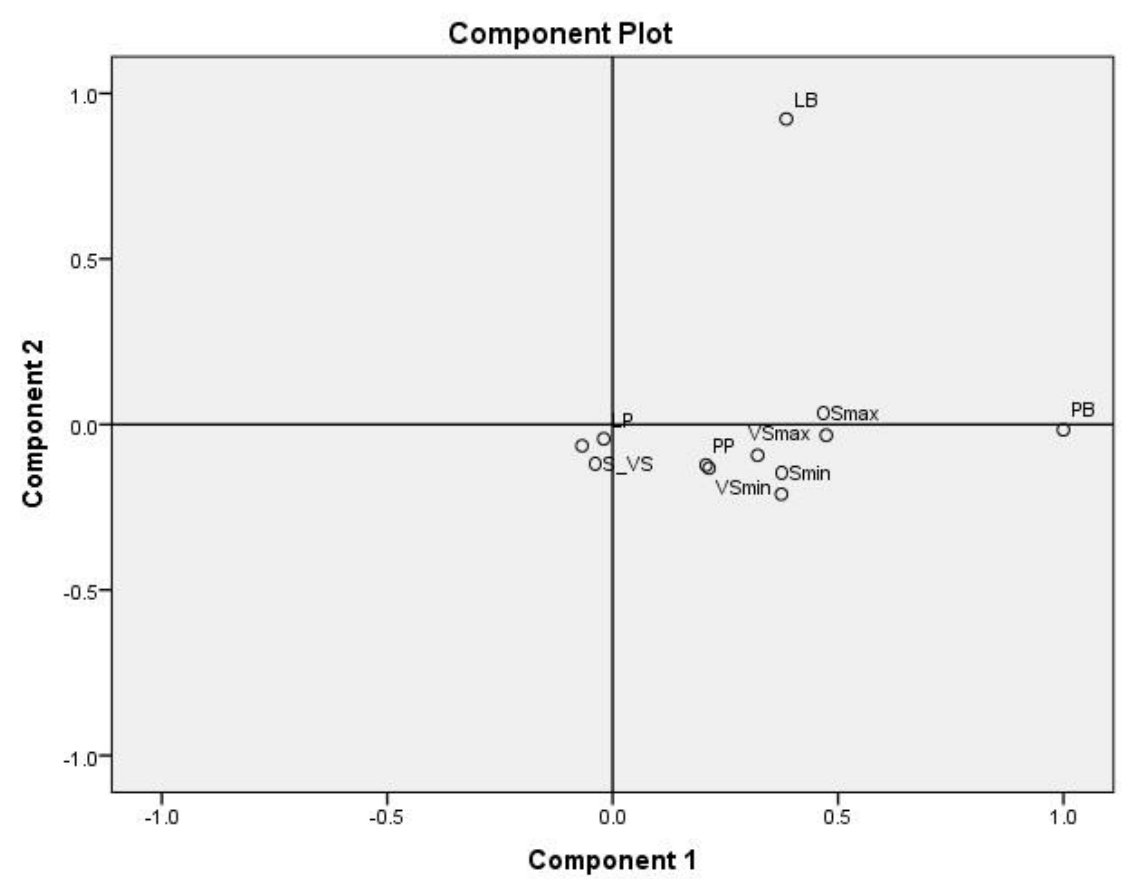

Figure 1. The result of Principal Component Analysis - Covariance test

Morphometric variation of Fasciola gigantica

In Figure 5 shows the variation of morphometry distributed in one field. Each pattern in the image has its own ID. Two groups of patterns were seen, which were groups of squares and triangles. This shows that the morphometry of Fasciola gigantica with box and triangle IDs has the most different sizes from each other. While the sample with the box ID and cross appears to be in the same pattern horde, this shows that both IDs have almost the same size. (Figure 2) 


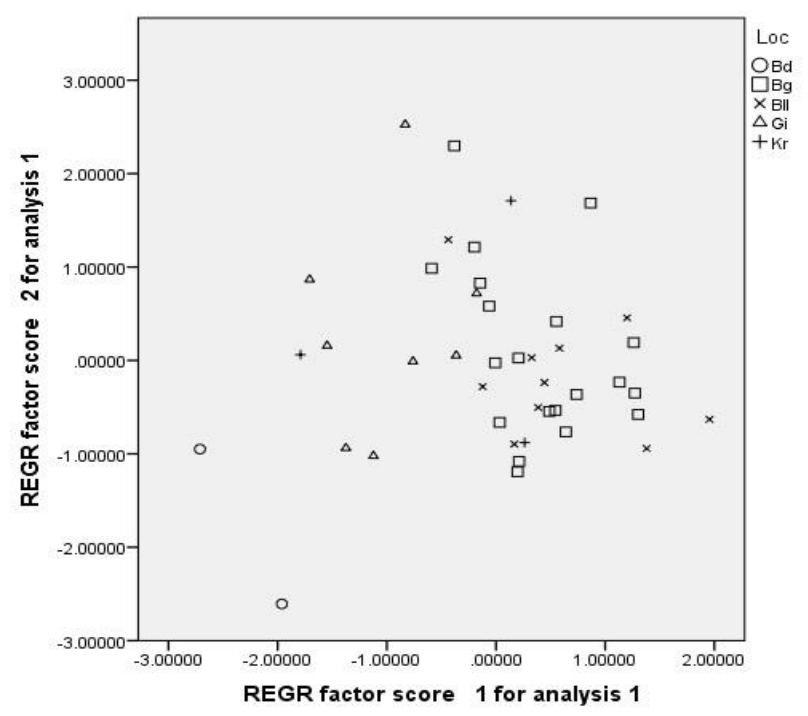

Figure 2. Variation of Fasciola gigantica morphometry

From the results of Fasciola morphometry, two variables were found to be differentiating factors, namely PB

\section{Body Length}

Judging from the results of the research that has been done, the lowest and highest PB (Body Length) value is 16,064 - 36,484 $\mathrm{mm}$ with an average value of $27,874 \mathrm{~mm}$. Other studies conducted in several other countries such as Iran, Egypt, Pakistan and India show significant differences with research that has been conducted in Bali. The results of the study in Iran [15] showed the lowest and highest PB (Body Length) size of Fasciola gigantica was 27.22 - $51.19 \mathrm{~mm}$ with an average value of $41.08 \mathrm{~mm}$. Periago stated in his research conducted in Egypt that the lowest and highest size was 35.25-48.71 $\mathrm{mm}$ with an average value of $44.65 \mathrm{~mm}$ [13]. Research conducted by Saira shows the lowest and highest size is 20.1-41.3 $\mathrm{mm}$ with an average value of $33.89 \mathrm{~mm}$ [17]. Different results were also obtained [12] namely the lowest and highest values ranged from $27 \mathrm{~mm}$ to $45 \mathrm{~mm}$ with an
(Body Length) and LB (Body Width) (Figure 4), while the other seven variables were not significant differentiating factors.

average value of $33.66 \mathrm{~mm}$. Other studies in Africa show a range of PB (Body Length) values from 30.7 to $52.0 \mathrm{~mm}$ with an average value of $39.5 \mathrm{~mm}$ [1].

\section{Body Width}

Based on the results of morphometric measurements obtained the lowest and highest values of LB (Body Width) are 3,421 - 8,257 $\mathrm{mm}$ with an average value of $6,377 \mathrm{~mm}$. Research conducted by Periago in Iran shows different results, namely the lowest and highest value of LB (Body Width) is 5.15 $9.80 \mathrm{~mm}$ and the average value is $6.92 \mathrm{~mm}$ while the lowest value and the highest in Egypt was $8.23-13.60 \mathrm{~mm}$ with an average value of $10.36 \mathrm{~mm}$ [13]. Other research in Iran by Reza shows that the LB range is $7.03-8.98 \mathrm{~mm}$ with an average of $8.14 \mathrm{~mm}$. In Thailand [15], the LB range is 6-14 $\mathrm{mm}$ with an average of $9.88 \mathrm{~mm}$ [18]. While the research conducted in Africa by 
Ashrafi showed the lowest and highest value was $6.5-11.4 \mathrm{~mm}$ with an average value of $8.9 \mathrm{~mm}[1]$.

Size and shape variation of Fasciola gigantica

According to the results of research conducted in several countries such as Egypt, Iran, Pakistan, India and Africa, the morphometry of Fasciola gigantica has a larger size than the size of liver fluke in Bali in terms of several variables that have significant differences such as PB (Body Length) and LB (Body Width). Phenotypic differences can be influenced by environment and genetics which have the potential to be the dominant factor causing the size variation of Fasciola gigantica in Bali. In many cases, phenotypic variations are present in populations of free-living species and become clearer when they come from different geographical locations or real changes in their environment [13].

Based on the results of the study, obtained two variables that are characteristic of the differentiator of Fasciola gigantica, namely PB (Body Length) and LB (Body Width) when viewed from the shape and size. This is shown in Figure 4 where the two variables move away from the center point of Components 1 and 2. The same thing is stated by Periago that the dominant variable giving a difference is BR (Body Roundness), BL (Body Length) / BW (Body Width) and VS-P (distance between ventral sucker and posterior body) [13]. Through these three variables, the results of the intermediate form of Fasciola gigantica worms in Iran and Egypt were obtained.

Cluster analysis from Principal Component Analysis - Covariance shows two different groups based on size, namely groups with Gianyar and Bangli IDs. The two groups looked away from each other and clustered on different sides.

Many studies have reported that morphometric patterns depend on host species [16],[19],[20],[8],[11],[1].

Furthermore, Ghavami states that differences in morphometry can be influenced by the intensity of infection, age and immune reactions caused by previous infections [5].

\section{The Intermediet Form of Fasciola gigantica}

The morphometry results of Fasciola gigantica studied in Bali not only have significant differences between regions in Bali but also overall differ from the existing Fasciola gigantica morphometry. Researchers found that PB and LB sizes tend to be smaller than Fasciola gigantica species in general.

Similar events regarding overlapping morphometry also occur in several other countries. The identified species include Fasciola hepatica, Fasciola gigantica and intermediate forms involving phenomena such as abnormal gametogenesis, diploidy, triploidy and mixoploidi, parthenogenesis, and hybridization events between different genotypes [10].

Sahba states that the length of Fasciola gigantica $(4.39-5.2 \mathrm{~cm})$ is longer than that of Fasciola hepatica (1.88-2.33 $\mathrm{cm}$ ) and other forms that have a length between the two measures have been reported as Fasciola indica [16].

Intermediate form phenomena are also reported in the province of Gilan, Iran, where fascioliasis causes serious health problems, including a large human epidemic [1]. The study of the identification of Fasciola species in Japan showed three types of morphology namely Fasciola gigantica, Fasciola hepatica and intermediates [10].

Morphometry of Fasciola gigantica on the island of Bali shows a smaller size than Fasciola gigantica in general but is greater than Fasciola hepatica. This raises the possibility that the Fasciola species that exist in Bali are intermediate species, seeing an overlap in size. Further molecular testing is needed to 
determine the extent to which morphometric differences affect genetics of Fasciola gigantica.

\section{CONCLUSIONS}

Based on the results of the study, the morphometry of Fasciola gigantica in Bali cattle was smaller than Fasciola gigantica in general, but larger than Fasciola hepatica, PB 27,874 mm, LB 6,378 mm, OSMax 0,122 mm, OSMin 0,112 mm, VSMax 0,204 mm, VSMin 0,195 mm, PP 0,109 mm, $0.070 \mathrm{~mm} \mathrm{LP}$ and $0.158 \mathrm{~mm}$ OS-VS. This shows that Fasciola gigantica species in Bali are intermediate species

\section{ACKNOWLEDGMENT}

The authors would like to thanks the Head of Mambal Slaughter House as well as all employees and all parties involved in assisting the completion of this research.

\section{REFERENCES}

[1] Ashrafi, K, Valero, M.A, Panova, M. Periago, M.V. Massoud, J. and MasComa, S. 2006. Phenotypic analysis of adults of Fasciola hepatica, Fasciola gigantica and intermediate forms from the endemic region of Gilan, Iran. Parasitol Int, 55:249260.

[2] Esteban J G; Gonzalez C; Curtale F; MunozAntoli C; Valero $\mathrm{M}$ A; Bargues M D; El Sayed M; El Wakeel A; Abdel-Wahab Y; Montresor A; Engels D; Savioli L and Mas-Coma S (2003): Hyperendemic fascioliasis associated with schistosomiasis in villages of the Nile Delta, Egypt. Am. J. Trop. Med. Hyg., 69: 429- 437.

[3] Fajar Mubarok, Nyoman Adi Suratma, I Made Dwinata. 2015. Prevalensi Trematoda di Sentra Pembibitan Sapi Bali Desa

Sobangan, Kecamatan Mengwi, Kabupaten Badung. Indonesia Medicus Veterinus 2015 4(1) : 48-53

[4] Farag, H.F., Barakat, R.M., Ragab, M., Omar, E. (1979) A focus of human fascioliasis in the Nile Delta, Egypt. The American Journal of Tropical Medicine and Hygiene 82,188-190.

[5] Ghavami, M.B. Rahimi, P. Haniloo, A. and Mosavinasab, S.N. 2009. Genotypic and phenotypic analysis of Fasciola isolates. Iran J Parasitol, 4(3):61-70

[6] Jusmaldi dan Saputra Y. 2009. Prevalensi Infeksi Cacing Hati (Fasciola hepatica) pada Sapi Potong di Rumah Potong Hewan Samarinda. Jurusan Biologi FMIPA Universitas Mulawarman. Bioprospek. Vol. 6 No. 2.

[7] Kaplan, R.M. 2001. Fasciola hepatica: a review of the economic impact in cattle and considerations for control. Vet.Therapeutics. 2(1):111

[8] Lotfy W M; El-Morshedy $\mathrm{H} \mathrm{N}$; Abou El-Hoda M; El-Tawila M M; Omar E A and Farag H F. 2002. Identification of the Egyptian species of Fasciola. Veterinary Parasitology 103323-332.

[9] Martindah E, Widjajanti S, Estuningsih SE, Suhardono. 2005. Meningkatkan Kesadaran dan Kepedulian Masyarakat Terhadap Fasciolosis Sebagai Penyakit Infeksius. Wartazoa Vol. 15.

[10] Mas-Coma, S., Bargues, M.D., 1997. Human liver flukes: a review. Res. Rev. Parasitol. 57, 145-218.

[11] Mas-Coma, S., Bargues, M.D.,Valero, M.A. 2005. Fascioliasis and otherplantborne trematode zoonoses. Int. J. Parasitol. $35,1255-1278$.

[12] Nazima Gul, Hidayatullah Tak, Younis Hazari dan Mohmad Yousuf. 2013. Comparative Morphometric Assessment and Protein Profiling of 
Fasciola hepatica and Fasciola gigantica Coexisting in Bovines. International Journal of Current Research Vol. 5, Issue, 06, pp.15941596.

[13] Periago MV, Valero MA, El Sayed M, Ashrafi K, El Wakeel A, Mohamed MY, Desquesnes M, Curtale F, Mas-Coma S. 2008. First phenotypic description of Fasciola hepatica/Fasciola gigantica intermediate forms from the human endemic area of the Nile Delta, Egypt. Infect Genet Evol, 8:51-58.

[14] Purwanta, Ismaya, Burhan. 2006. Penyakit Cacing Hati (Fascioliasis) Pada Sapi Bali di Perusahaan Daerah Rumah Potong Hewan (RPH) Kota Makassar. Jurnal Agrisistem. Vol. 2 No. 2.

[15] Reza Shafiei, Bahador Sarkari, Seyed Mahmuod Sadjjadi, Gholam Reza Mowlavi, dan Abdolali Moshfe. 2014. Molecular and Morphological Characterization of Fasciola spp. Isolated from Different Host Species in a Newly Emerging Focus of Human Fascioliasis in Iran. Hindawi Publishing Corporation Veterinary Medicine International Volume 2014, Article ID 405740.

[16] Sahba, G.H., Arfaa, F., Farahmandian, I., Jalali, H. 1972. Animal fascioliasis in Khuzestan, southwestern Iran. Journal of Parasitology 58, 712-716.
[17] Saira Mufti, M. Maqbool Ahmad, Yusuf Zafar, and Mazhar Qayyum. 2011. Phenotypic Analysis of Adult Fasciola spp. From Potohar Region of Northern Punjab, Pakistan. Pakistan J. Zool., vol 43(6), pp. 1069-1077.

[18] Srimuzipo, P., Komalamisra, C., Choochote, W., Jitpakdi, A., Vanichthanakorn, P., Keha, P., Riyong, D., Sukontasan, K., Komalamisra, N., Sukontasan, K., Tippawangkosol, P. (2000) Comparative morphometry, morphology of egg and adult surface topography under light and scanning electron microscopies, and metaphase karyotype among three sizeraces of Fasciola gigantica in Thailand. The Southeast Asian journal of tropical medicine and public health 31, 366-373.

[19] Terasaki, K., Noda, Y., Shibahara, T., Itagaki, T., 2000. Morphological comparisons and hypotheses on the origin of polyploids in parthenogenetic Fasciola sp. J. Parasitol. 86, 724-729.

[20] Valero, M.A., Panova, M., MasComa, S., 2001. Developmental differences in the uterus of Fasciola hepatica between livestock liver fluke populations from Bolivian highland and European lowlands. Parasitol. Res. 87, 337- 342. 